\title{
Engineering a Microbial Consortium Based Whole-Cell System for Efficient Production of Glutarate From L-Lysine
}

\author{
Xin Wangt, Rui Sut, Kequan Chen*, Sheng Xu, Jiao Feng and Pingkai Ouyang \\ State Key Laboratory of Materials-Oriented Chemical Engineering, College of Biotechnology and Pharmaceutical \\ Engineering, Nanjing Tech University, Nanjing, China
}

\section{OPEN ACCESS}

Edited by:

Thomas E. Hanson, University of Delaware, United States

Reviewed by:

Vinod Kumar,

Cranfield University, United Kingdom

Charilaos Xiros,

Research Institutes of Sweden (RISE),

Sweden

Jian-Zhong Liu,

Sun Yat-sen University, China

*Correspondence:

Kequan Chen

kqchen@njtech.edu.cn

tThese authors have contributed equally to this work

Specialty section:

This article was submitted to Microbial Physiology and Metabolism, a section of the journal

Frontiers in Microbiology

Received: 26 September 2018 Accepted: 08 February 2019

Published: 26 February 2019

Citation:

Wang X, Su R, Chen K, Xu S,

Feng $J$ and Ouyang $P$ (2019)

Engineering a Microbial Consortium Based Whole-Cell System for Efficient

Production of Glutarate From

L-Lysine. Front. Microbiol. 10:341. doi: 10.3389/fmicb.2019.00341
Glutarate is an important C5 platform chemical produced during the catabolism of L-lysine through 5-aminovalerate (5-AMV) pathway. Here, we first established a whole-cell biocatalysis system for the glutarate production from L-lysine with the engineered Escherichia coli (E. coli) that co-expressed DavAB and GabDT. However, the accumulation of intermediate 5-AMV was identified as one important factor limiting glutarate production. Meanwhile, the negative interaction of co-expressing DavAB and GabDT in a single cell was also confirmed. Here, we solved these problems through engineering a microbial consortium composed of two engineered E. coli strains, BL2122AB and BL21-YDT, as the whole-cell biocatalysts, each of which contains a part of the glutarate pathway. After the optimization of bioconversion conditions, including temperature, metal ion additives, $\mathrm{pH}$, and cell ratio, $17.2 \mathrm{~g} / \mathrm{L}$ glutarate was obtained from $20 \mathrm{~g} / \mathrm{L}$ L-lysine with a yield of $95.1 \%$, which was improved by $19.2 \%$ compared with that in a single cell. Little accumulation of 5-AMV was detected. Even at the high substrate concentration, the reduced 5-AMV accumulation and increased glutarate production were achieved. This synthetic consortium produced $43.8 \mathrm{~g} / \mathrm{L}$ glutarate via a fed-batch strategy, the highest titer reported to date.

Keywords: glutarate, 5-aminovalerate accumulation, engineering microbial consortium, whole-cell, E. coli

\section{INTRODUCTION}

As the seriousness of environmental problems related to global warming and depletion of oil reserves, the development of sustainable bio-process for petroleum-derived chemicals has attracted increased attention in recent years (Tsuge et al., 2016). Dicarboxylic acids, especially aliphatic dicarboxylic acids, such as succinate, glutarate, adipate, pimelate, and suberate, are important building blocks for the synthesis of polymers and polyamides, such as polyurethanes, polyester polyols and polyamides (Okino et al., 2008; Gobin et al., 2015). Nylon is one of the most important polymers, and produced by copolymerization of various dicarboxylic acids with diamines. Glutarate, as an important C5 building block, has been widely used for the production of nylon, such as nylon-4,5 (a co-polymer of putrescine and glutarate) and nylon-5,5 (a copolymer of cadaverine and glutarate) (Williams et al., 2003; Adkins et al., 2013; Baldwin et al., 2015; Zhao et al., 2016). For the chemical synthesis of glutarate, a mixture of cyclohexanone, and 
cyclohexanol (KA oils) was oxidized with nitric acid (Paris et al., 2003; Vafaeezadeh and Hashemi, 2016). However, the cost and environmental concern of chemical methods limited the sustainable production of glutarate in industry. Hence, the efficient bio-based process for glutarate production is highly desired.

A natural pathway for producing glutarate by the four-step degradation of lysine has been identified in Pseudomonas putida (P. putida) (Adkins et al., 2013; Park et al., 2013; Liu et al., 2014; Rohles et al., 2016), which was also called the 5-aminovalerate (5-AMV) pathway. In this pathway, L-lysine was oxidized to generate 5-aminovaleramide by L-lysine monooxygenase (encoded by $\operatorname{DavB}$ ), which is then converted to 5-AMV by 5 -aminovaleramide amidohydrolase (encoded by $\operatorname{DavA}$ ). Thenceforth, 5-AMV is converted into glutarate via glutarate semialdehyde by aminovalerate aminotransferase (encoded by GabT) and succinate semialdehyde dehydrogenase (encoded by $G a b D)$. The conversion of 5-AMV into glutarate semialdehyde employs $\alpha$-ketoglutarate ( $\alpha-\mathrm{KG}$ ) as the acceptor for amine group. However, glutarate was not found in the natural metabolites of $P$. putida. Based on this pathway, the highest glutarate titer of $1.7 \mathrm{~g} / \mathrm{L}$ has been achieved in recombinant E. coli (Park et al., 2013). In recent years, several other artificial glutarate biosynthetic pathways were also developed. For example, by incorporation of a " +1 " carbon chain extension pathway from $\alpha-\mathrm{KG}$ in combination with $\alpha$-keto acid decarboxylation, $0.42 \mathrm{~g} / \mathrm{L}$ of glutarate was successfully obtained in the recombinant E. coli (Wang et al., 2017). Yu et al. also constructed a novel glutarate biosynthetic pathway from $\alpha-K G$ reduction by expressing eight genes in E. coli, and $3.8 \mathrm{mg} / \mathrm{L}$ of glutarate was finally produced (Yu et al., 2017). However, the glutarate production via the de novo biosynthesis strategy from glucose remained far below that required for economic applicability due to the long fermentation period and low conversion rate. Thus, it would be desirable to find other alternative method for the biotechnological production of glutarate.

We have developed an efficient whole-cell biocatalysis process for high-level conversion of L-lysine into 5-AMV with a final titer of $240.7 \mathrm{~g} / \mathrm{L}$ previously (Wang et al., 2016). It is well known that fermentation of high concentrations of L-lysine is easily carried out, and annual production of L-lysine reached more than two million tons currently (Eggeling and Bott, 2015). As the fastest growing segment within the amino acid market, L-lysine is readily available at a reasonable price, about $1500 \$$ per ton. With L-lysine as a starting material, a variety of valuable chemicals have been produced, such as cadaverine (Ma et al., 2015; Oh et al., 2015), pipecolic acid (Ying et al., 2015), and 5-AMV (Adkins et al., 2013; Park et al., 2013, 2014; Wang et al., 2016). As glutarate has a price of about $9500 \$$ per ton, considering these factors, producing glutarate by bioconversion of lysine based on a whole-cell biocatalytic process seems feasible.

In this study, a recombinant $E$. coli was constructed to produce glutarate by the conversion of L-lysine through the overexpression of $D a v B, D a v A, G a b T$, and GabD involved in 5AMV pathway. When the whole-cell biocatalysis was performed by E. coli BL21-DavAB-GabDT, the accumulation of intermediate 5-AMV was detected and largely restricted glutarate productivity.
Furthermore, we confirmed that the co-expression of DavAB and GabDT in a single cell negatively affected the activity each other. Several metabolic engineering strategies have been employed to solve the intermediate accumulation problems, such as increasing the expression strength of the downstream gene by means of promoter libraries (Miksch et al., 2005), mRNA stability (Smolke et al., 2001), or ribosome binding strength (Salis et al., 2009), and dynamic control of pathway enzymes using intermediate-sensitive promoters (Dahl et al., 2013). Among these methods, the synthetic microbial consortium has attracted researchers' attention in recent years for the production of valuable metabolites (Lu et al., 2014; Chen and Nielsen, 2016; Yang et al., 2018). As a result, a novel microbial consortia based whole-cell system was engineered by expression of $D a v A B$ and GabDT in two divided E. coli strains for glutarate production. The benefits and features of microbial consortia were subsequently characterized with the highest glutarate titer reported to date.

\section{MATERIALS AND METHODS}

\section{Microorganisms and Media}

All microbial strains employed in this study are listed in Table $\mathbf{1 .}$ E. coli strains were cultured at $37^{\circ} \mathrm{C}$ in Luria-Bertani medium (10 g/L peptone, $5 \mathrm{~g} / \mathrm{L}$ yeast extract, and $5 \mathrm{~g} / \mathrm{L}$ sodium chloride) and antibiotics were added at the following concentrations: $100 \mathrm{mg} / \mathrm{L}$ ampicillin (Amp), $35 \mathrm{mg} / \mathrm{L}$ chloramphenicol (Cm), and $50 \mathrm{mg} / \mathrm{L}$ kanamycin (Kan).

\section{Plasmids Construction}

All plasmids used or constructed in this study were listed in Table 1. pET22b-DavAB was constructed by sequential insertion of synthesized DavB and DavA genes from Pseudomonas putida (P. putida) KT2440 into pET22b at the NdeI/XhoI and

TABLE 1 | Strains and plasmids used in this study.

\begin{tabular}{|c|c|c|}
\hline Strains or plasmids & Description & References \\
\hline \multicolumn{3}{|l|}{ E. coli strains } \\
\hline BL21(DE3) & Used as host strain & Invitrogen \\
\hline$B L 21-22 A B$ & $\begin{array}{l}\text { E. coli BL21(DE3) harboring plasmid } \\
\text { pET22b-DavAB }\end{array}$ & This study \\
\hline BL21-YDT & $\begin{array}{l}\text { E. coli BL21(DE3) harboring plasmid } \\
\text { pACYC-GabDT }\end{array}$ & This study \\
\hline BL21-22AB-YDT & $\begin{array}{l}\text { E. coli BL21(DE3) harboring plasmid } \\
\text { pET22b-DavAB and pACYC-GabDT }\end{array}$ & This study \\
\hline \multicolumn{3}{|l|}{ Plasmids } \\
\hline pET22b & $\begin{array}{l}\text { expression vector, } \mathrm{Amp}^{R}, \mathrm{P}_{T 7}, \mathrm{pBR} 322 \\
\text { ori }\end{array}$ & This study \\
\hline pACYCDuet-1 & expression vector, $\mathrm{Cm}^{R}, \mathrm{P}_{T 7}, \mathrm{P} 15 \mathrm{~A}$ ori & This study \\
\hline pACYC-GabDT & $\begin{array}{l}\text { Gene GabD inserted between Ncol and } \\
\text { Hindlll sites of pACYCDuet- } 1 \text { and GabT } \\
\text { inserted between Ndel and Xhol sites of } \\
\text { pACYCDuet-1 }\end{array}$ & This study \\
\hline pET22b-DavAB & $\begin{array}{l}\text { Gene DavA inserted between Agel and } \\
\text { Xmal sites of pET22b and DavB } \\
\text { inserted between Ndel and Xhol sites of } \\
\text { pET22b }\end{array}$ & This study \\
\hline
\end{tabular}




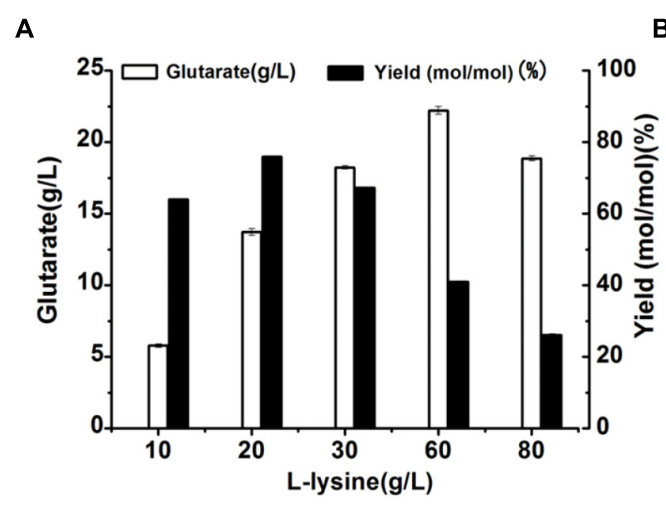

\section{B}

FIGURE 1 | Recombinant whole-cell bioconversion for glutarate production via co-expression of DavAB and GabDT in E. coli BL21(DE3). (A) The glutarate production under the different initial concentrations of L-lysine after bioconversion of $70 \mathrm{~h}$; (B) The L-lysine and $\alpha$-ketoglutarate ( $\alpha$-KG) residue, and 5-AMV accumulation in the whole-cell bioconversion system under the different initial concentrations of L-lysine after bioconversion of $70 \mathrm{~h}$.
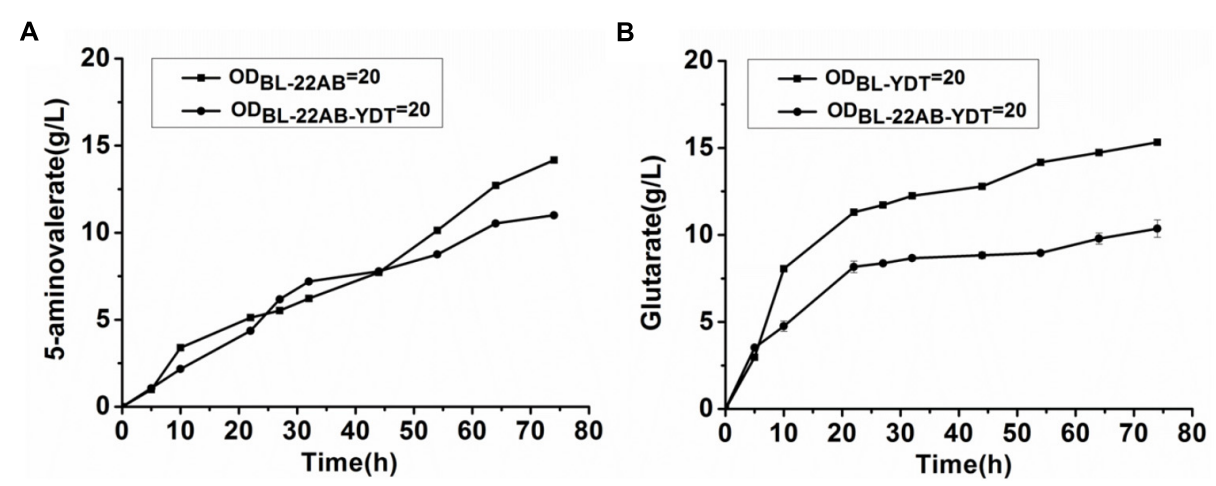

FIGURE 2 | The negative interactions of co-expressing DavAB and GabDT in E. coli BL21(DE3). (A) The influence of expressing GabDT on DavAB activity. The in vivo DavAB activity in strain BL21-22AB was compared to that in the strain BL21-22AB-YDT; (B) The influence of expressing DavAB on GabDT activity. The in vivo GabDT activity in strain BL21-YDT was compared to that in the strain BL21-22AB-YDT.

AgeI/XmaI sites, respectively. pACYC-GabDT was constructed by sequentially cloning the GabT and GabD genes from P. putida KT2440 into pACYCDuet-1 at the NdeI/XhoI and NcoI/HindIII sites, respectively. Expression of all genes was confirmed by sodium dodecyl sulfate polyacrylamide gel electrophoresis (SDSPAGE) analysis.

\section{DavAB and GabDT Activities in vivo}

$D a v A B$ and GabDT, expressed in E. coli with the plasmid pET22b$D a v A B$ and pACYC-GabDT, were subjected to enzyme activity assays. The DavAB assay mix contained resting cells BL21-22ABYDT $\left(\mathrm{OD}_{600}=5\right)$ and $5 \mathrm{~g} / \mathrm{L}$ L-lysine in $50 \mathrm{mM}$ PBS buffer $(\mathrm{pH}$ 7.0) in a total volume of $10 \mathrm{~mL}$. Reactions were performed at $37^{\circ} \mathrm{C}$ for $3 \mathrm{~h}$. Samples were removed and determined by highperformance liquid chromatography (HPLC) (described below). One unit (U) of DavAB activity was defined as $1 \mu$ mol 5-AMV produced per min under the described conditions. For calculating specific units (U/mg protein), the protein concentration was estimated based on the $\mathrm{OD}_{600}$ of the culture and the assumption that $1 \mathrm{~L}$ culture with an $\mathrm{OD}_{600}$ of 1 contains $0.250 \mathrm{~g}$ of biomass of which half is assumed to be protein.
The GabDT assay mix contained resting cells BL21-22ABYDT $\left(\mathrm{OD}_{600}=5\right), 12 \mathrm{~g} / \mathrm{L} \alpha-\mathrm{KG}$, and $5 \mathrm{~g} / \mathrm{L} 5-\mathrm{AMV}$ in $50 \mathrm{mM}$ PBS buffer $(\mathrm{pH} 7.0)$ in a total volume of $10 \mathrm{~mL}$. Reactions were performed at $37^{\circ} \mathrm{C}$ for $3 \mathrm{~h}$. Samples were removed and determined by HPLC (described below). One unit (U) of GabDT activity was defined as $1 \mu \mathrm{mol}$ glutarate produced per min under the described conditions. For calculating specific units (U/mg protein), the protein concentration was estimated based on the $\mathrm{OD}_{600}$ of the culture and the assumption that $1 \mathrm{~L}$ culture with an $\mathrm{OD}_{600}$ of 1 contains $0.250 \mathrm{~g}$ of biomass of which half is assumed to be protein.

\section{Preparation and Optimization of the Whole-Cell Biocatalysts}

Recombinant strain was inoculated into $5 \mathrm{~mL} \mathrm{LB}$ medium with desirable antibiotics from a freshly transformed single colony at $37^{\circ} \mathrm{C}$ for $8 \mathrm{~h}$. Then the seed culture was transferred into $100 \mathrm{~mL}$ LB medium in baffled Erlenmeyer flasks with an initial optical density $\left(\mathrm{OD}_{600}\right)$ of 0.05 . Cell densities were detected by UV spectrophotometry at $600 \mathrm{~nm}$. When $\mathrm{OD}_{600}$ reached $0.3,0.6$, 1.0 , or 2.0 approximately, the cultures were induced by $0.1,0.25$, 


\section{A}

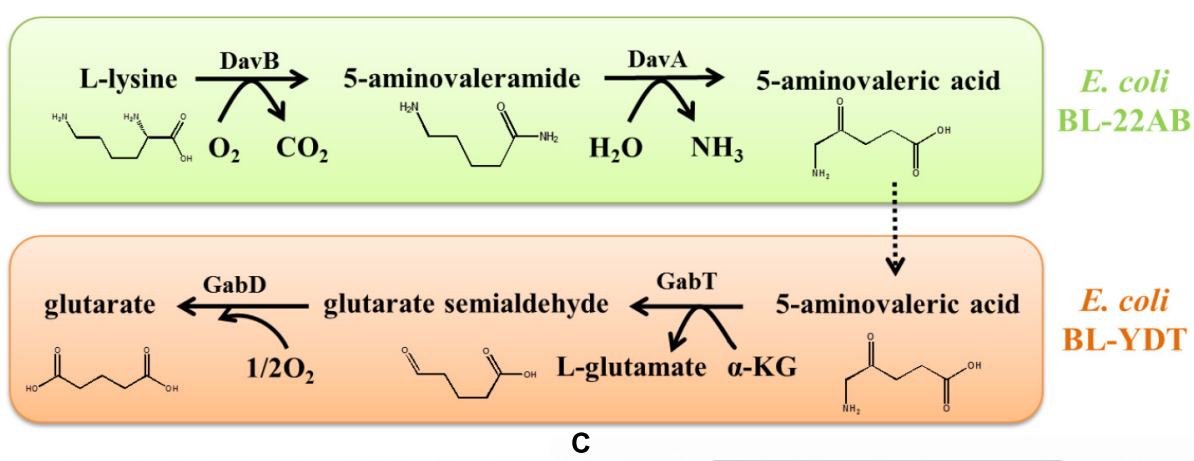

B

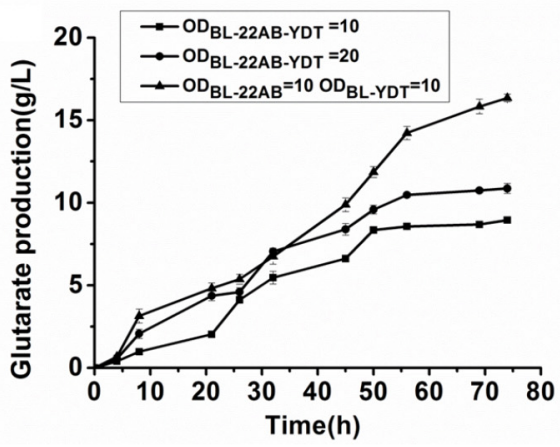

C

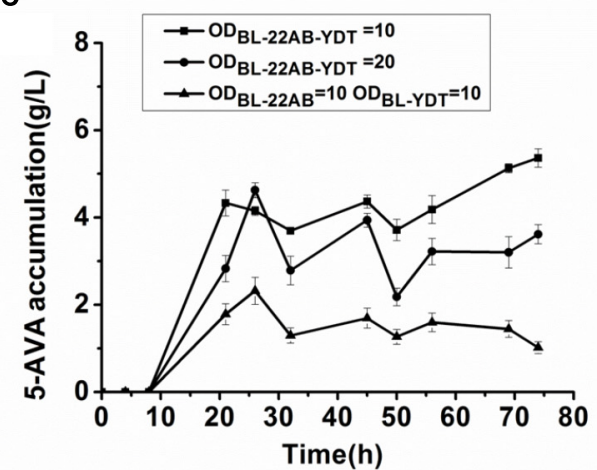

FIGURE 3 | Engineering a synthetic microbial consortium based whole-cell system for production of glutarate from L-lysine. (A) A schematic of the synthetic microbial consortium for glutarate production; (B) Glutarate production in the synthetic microbial consortium; (C) 5-AMV accumulation in the synthetic microbial consortium.

0.5 , or $1.0 \mathrm{mM}$ IPTG at $15,20,25,30$, or $37^{\circ} \mathrm{C}$, respectively, to optimize the gene expression. After $12 \mathrm{~h}$ of incubation, cells were harvested by centrifugation at $4000 \times g$ for $10 \mathrm{~min}$, discarding the supernatant and washing twice in cold $50 \mathrm{mM}$ PBS buffer ( $\mathrm{pH}$ 7.0). Finally, the cells were re-suspended in PBS buffer as the whole-cell biocatalysts.

\section{Recombinant Whole-Cell Bioconversion for Glutarate Production}

The whole-cell bioconversion was carried out in a $50 \mathrm{~mL}$ flask with $20 \mathrm{~mL}$ reaction broth containing resting cells BL2122AB-YDT $\left(\mathrm{OD}_{600}=20\right)$, adding different concentrations of L-lysine and $\alpha-\mathrm{KG}$ with the molar ratio of $1: 1$ and the rest were complemented with $50 \mathrm{mM}$ PBS buffer ( $\mathrm{pH} 7.0$ ). The added content of L-lysine was 10, 20, 30, 60, and $80 \mathrm{~g} / \mathrm{L}$, respectively, $\alpha-\mathrm{KG}$ the same. The $\mathrm{pH}$ value was controlled at about 7.0 with phosphoric acid and sodium hydroxide solutions. The reaction was performed at the temperature of $37^{\circ} \mathrm{C}$ and stirred at $200 \mathrm{rpm}$. Samples were taken at the specific intervals to measure the concentrations of glutarate, 5-AMV, L-lysine, and $\alpha-K G$.

In this section, the mutual effect of $\operatorname{DavAB}$ and GabDT activities based on the expression in a one cell was explored. The resting cells, including BL21-22AB-YDT, BL21-22AB, and BL21YDT were prepared as biocatalysts. To test the effect of DavAB expression on GabDT activity, the whole-cell transformation of 5-AMV to glutarate was carried out in a $20 \mathrm{~mL}$ reaction mixture containing $30 \mathrm{~g} / \mathrm{L} \alpha-\mathrm{KG}, 15 \mathrm{~g} / \mathrm{L} 5-\mathrm{AMV}$, and $50 \mathrm{mM}$
PBS buffer $(\mathrm{pH}=7.0)$ in a $50 \mathrm{~mL}$ flask with resting cells BL21-22AB-YDT $\left(\mathrm{OD}_{600}=20\right)$. As a contrast, the activity of the whole-cell BL21-YDT was determined at the same reaction conditions. To test the effect of GabDT expression on DavAB activity, the transformation of L-lysine to 5-AMV was carried out in a $50 \mathrm{~mL}$ flask containing $20 \mathrm{~g} / \mathrm{L}$ L-lysine with resting cells of BL21-22AB-YDT $\left(\mathrm{OD}_{600}=20\right)$, while the whole-cell BL21$22 \mathrm{AB}$ was used as the control. All the reaction was performed at the temperature of $37^{\circ} \mathrm{C}$ and stimulated with a paddle speed of $200 \mathrm{rpm}$ in a thermostatic shaker. Samples were taken at the specific intervals to measure the concentrations of substrates, products and intermediates.

\section{The Engineered Microbial Consortia for Whole-Cell Bioconversion}

The engineered microbial consortia including BL21-22AB $\left(\mathrm{OD}_{600}=10\right)$ and BL21-YDT $\left(\mathrm{OD}_{600}=10\right)$ was employed for whole-cell bioconversion of L-lysine to glutarate in the presence of $20 \mathrm{~g} / \mathrm{L} \alpha-\mathrm{KG}$ and $20 \mathrm{~g} / \mathrm{L}$ L-lysine. The reaction was also performed with $20 \mathrm{OD}_{600}$ of BL21-22AB-YDT and $10 \mathrm{OD}_{600}$ of BL21-22AB-YDT, respectively, as the control. The temperature was maintained at $37^{\circ} \mathrm{C}$ and stimulated with a paddle speed of $200 \mathrm{rpm}$ in a $1 \mathrm{~L}$ fermenter. Samples were taken at the specific intervals to measure the concentration of substrates, products, and intermediates.

To enhance glutarate yield, the effects of $\mathrm{pH}$, reaction temperature, metal ion, and cell ratio were investigated. The 
effect of temperature was determined by measuring the wholecell conversion activity between 20 and $55^{\circ} \mathrm{C}$ and the $\mathrm{pH}$ were between 5 and 8.2. To determine the metal ions preference, the effect of $\mathrm{Zn}^{2+}, \mathrm{Fe}^{3+}, \mathrm{Fe}^{2+}, \mathrm{K}^{+}, \mathrm{Mg}^{2+}, \mathrm{Co}^{2+}, \mathrm{Mn}^{2+}, \mathrm{Sr}^{2+}, \mathrm{Ca}^{2+}$, and $\mathrm{Cu}^{2+}(3 \mathrm{mM})$ additives was investigated. The proportion of BL21-22AB and BL21-YDT was adjusted to measure the reduction of intermediate products.

Fed-batch bioconversion was carried out in a $1 \mathrm{~L}$ fermenter with a total reaction mixture volume of $300 \mathrm{~mL}$. The recombinant strain was cultured and induced as described above. The reaction mixture containing resting cells BL21-22AB $\left(\mathrm{OD}_{600}=10\right)$ and BL21-YDT $\left(\mathrm{OD}_{600}=10\right), 20 \mathrm{~g} / \mathrm{L} \mathrm{L}$-lysine, $5 \mathrm{mmol} / \mathrm{L} \mathrm{Cu}^{2+}$, and $0.5 \%$ Triton $\mathrm{X}-100$ was incubated at $37^{\circ} \mathrm{C}$ with a speed of $200 \mathrm{rpm}$. Samples were taken at the specific intervals to measure L-lysine concentration. L-lysine powder was added into the reactor to maintain the substrate concentration at $20 \mathrm{~g} / \mathrm{L}$, when the L-lysine decreased to 1-2 g/L. Samples were taken at the specific intervals until the reactions reached equilibrium.

\section{Analytical Methods}

Cell growth was monitored by absorbance at $\mathrm{OD}_{600}$ by ultraviolet spectrophotometer. The quantity analysis of substrates and intermediates was performed by liquid chromatography. All samples were measured by two methods. The first method is the quantity of glutarate and $\alpha-K G$ which was performed by a HPLC system (Agilent 1260 series, Santa Clara, CA, United States) equipped with a UV-Vis detector and a Bio-Rad Aminex HPX$87 \mathrm{H}$ column $\left(300 \mathrm{~mm}^{*} 7.8 \mathrm{~mm}\right)$. The column temperature was maintained at $55^{\circ} \mathrm{C}$ and the mobile phase was $0.8 \mathrm{mM} \mathrm{H}_{2} \mathrm{SO}_{4}$ at a flow rate of $0.6 \mathrm{~mL} / \mathrm{min}$. To analyze the aqueous concentrations of L-lysine and 5-AMV, a HPLC (Agilent 1100 series, Santa Clara, CA, United States) system was used, which was equipped with an evaporative light scattering detector (ELSD) and a Prevail C18 column $\left(250^{*} 4.6 \mathrm{~mm}, 5 \mu \mathrm{m}\right.$, Bio-Rad, Hercules, CA, United States) at $28.5^{\circ} \mathrm{C} .0 .7 \%(\mathrm{v} / \mathrm{v})$ trifluoroacetic acid aqueous solution was used as the mobile phase at a flow rate of $1.0 \mathrm{~mL} / \mathrm{min}$. The product yield was calculated as follows: Glutarate yield $(\%)=\mathrm{C}(\mathrm{G}) / \mathrm{C}(\mathrm{L})$, where $\mathrm{C}(\mathrm{L})$ represents the initial L-lysine molar concentration, and C(G) represents the increased glutarate molar concentration after reaction.

\section{RESULTS}

\section{The Co-expression of DavAB and GabDT in a Single Cell to Produce Glutarate}

Here, we attempted to develop a whole-cell biocatalytic system for glutarate production from L-lysine. Accordingly, a recombinant $E$. coli BL21-22AB-YDT was constructed by coexpressing four genes of DavAB and GabDT in E. coli BL21(DE3) as the whole-cell catalysts. The SDS-PAGE illustrated that the protein $\operatorname{DavA}, \operatorname{DavB}, G a b D$, and GabT mainly existed in the supernatant, indicating a soluble expression (Supplementary Figure S1 and Supplementary Table S1). Subsequently, the bioconversion was carried out with the different concentrations of L-lysine ranging from 10 to $80 \mathrm{~g} / \mathrm{L}$. As shown in Figure 1A, the glutarate production improved with the increasing L-lysine

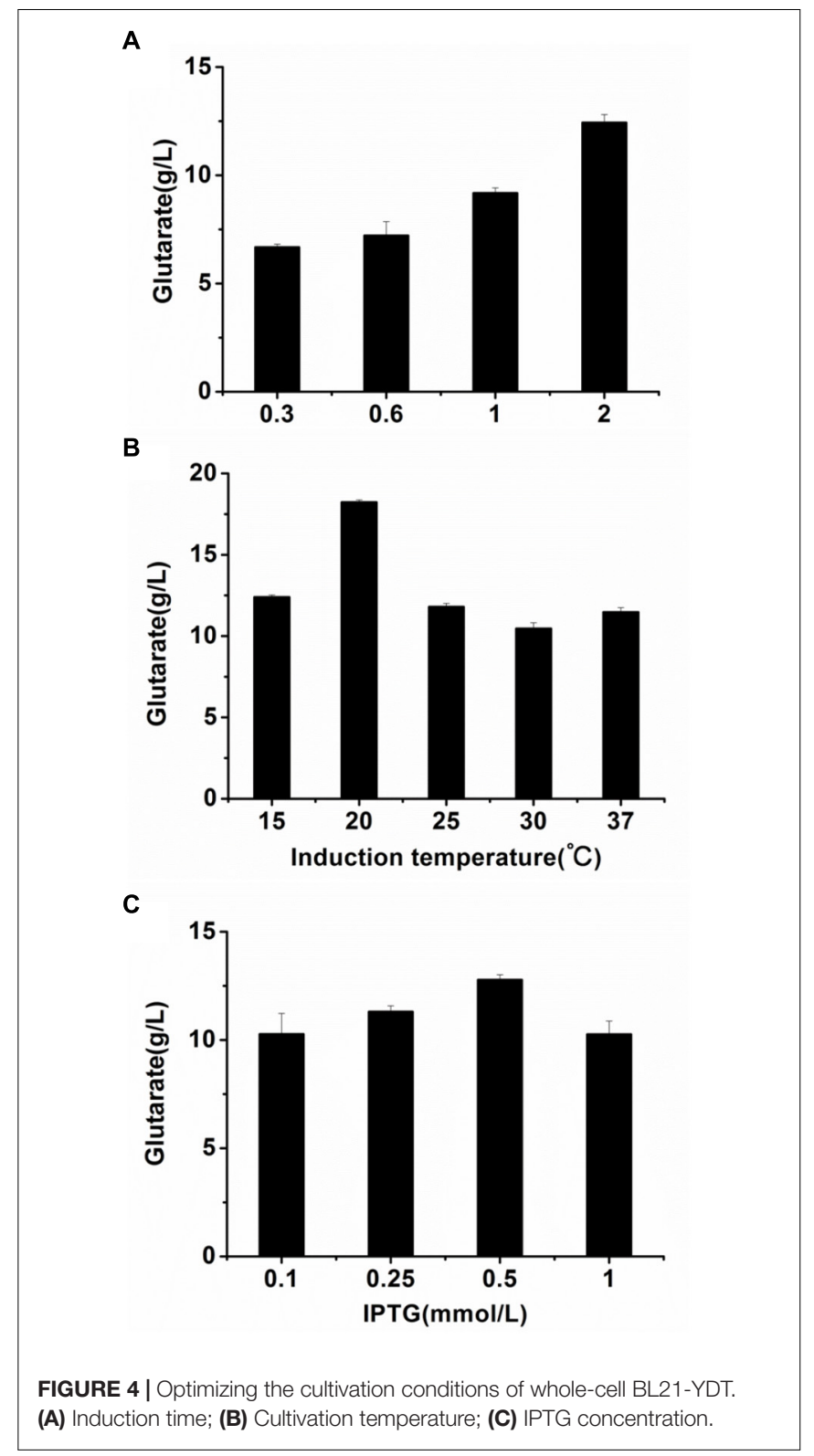

concentration, and reached the highest level $(22.2 \mathrm{~g} / \mathrm{L})$ at $60 \mathrm{~g} / \mathrm{L}$ L-lysine. Furthermore, we found that the highest glutarate molar yield was only $75.9 \%$ under the condition of $20 \mathrm{~g} / \mathrm{L}$ L-lysine. When the L-lysine concentration increased to $60 \mathrm{~g} / \mathrm{L}$, a lower molar yield of $41 \%$ was obtained, which was decreased to $26.1 \%$ at $80 \mathrm{~g} / \mathrm{L}$ lysine.

To explore the potential reasons involved in low yield of glutarate, the metabolite distribution in the bioconversion mixture was tested. As shown in Figure 1B, the intermediate 5-AMV was largely accumulated no matter what the initial concentration of L-lysine was. Under the condition of $20 \mathrm{~g} / \mathrm{L}$ L-lysine, 5-AMV accumulation from L-lysine was $4.6 \mathrm{~g} / \mathrm{L}$, while $17.2 \mathrm{~g} / \mathrm{L}$ 5-AMV was accumulated under the condition of $80 \mathrm{~g} / \mathrm{L}$ lysine. The 5-AMV accumulation reflected a 


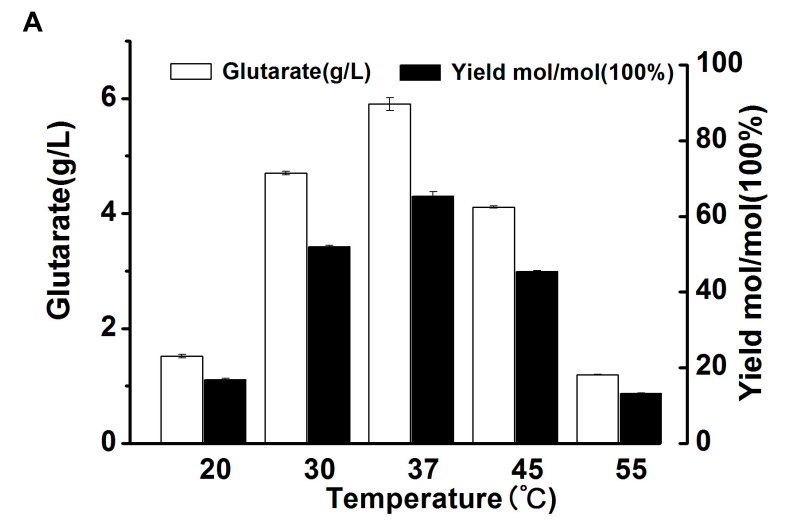

C

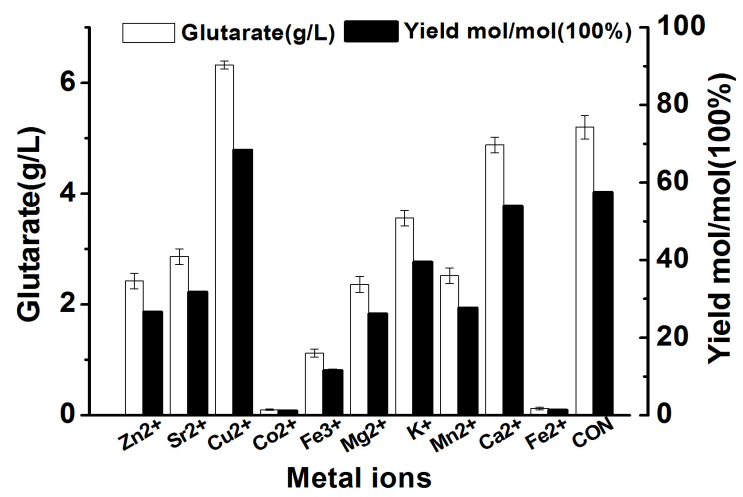

B

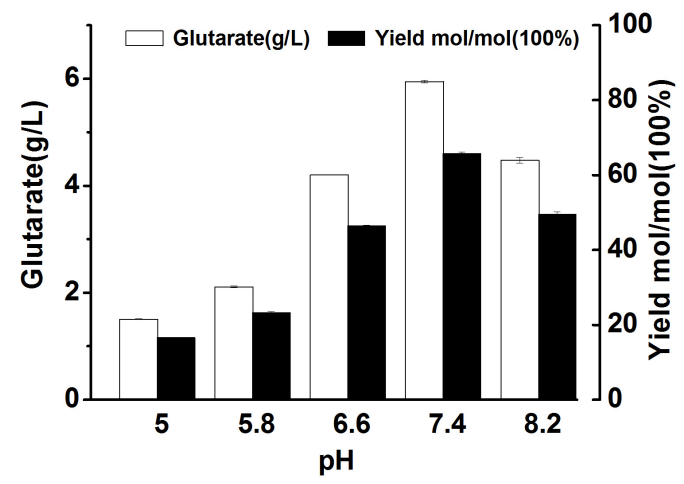

D

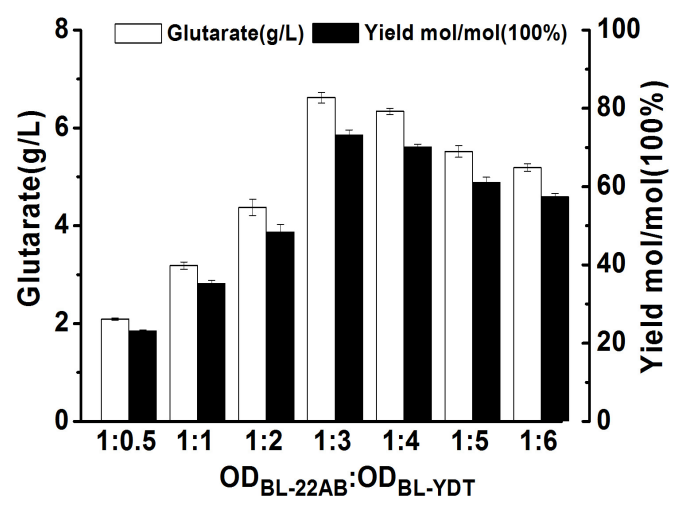

FIGURE 5 | Optimizing the bioconversion conditions of the microbial consortium based whole-cell system. (A) The effect of reaction temperature on glutarate production; (B) The effect of reaction pH on glutarate production; (C) The effect of metal ions on glutarate production; (D) The effect of cell ratio on glutarate production.

metabolic balance in the recombinant strain E. coli BL21$22 \mathrm{AB}-Y \mathrm{DT}$. To confirm it, the in vivo activity of DavAB and GabDT was measured. As a result, the in vivo activity of $D a v A B$ was $1.46 \mathrm{U} / \mathrm{mg}$ and the in vivo activity of GabDT was $0.3 \mathrm{U} / \mathrm{mg}$, indicating an imbalance of the $D a v A B$ and GabDT activities when they co-expressed in the recombinant strain BL21-22AB-YDT.

We attempted to enhance the expression of GabDT to decrease 5-AMV accumulation by optimization of plasmid copy numbers. However, the increased glutarate production was not found due to the formation of insoluble GabT protein (data not shown). Engineering a microbial consortium might be an alternative way to reduce the metabolic imbalance. We first comparatively analyzed the effect on activities of $D a v A B$ and GabDT when expressed in a single strain or two strains. The $\operatorname{Dav} A B$ activity difference in E. coli BL21-22AB-YDT and E. coli BL21-22AB was shown in Figure 2A. 5-AMV production by the whole cells of $E$. coli BL21-22AB-YDT was lower than that by E. coli BL21-22AB, indicating a decreased $D a v A B$ activity due to the expression of GabDT. Meanwhile, a lower GabDT activity of E. coli BL21-22AB-YDT was also identified compared to that of E. coli BL21-YDT through the detection of glutarate production from 5-AMV to $\alpha-K G$ (Figure 2B). These results displayed that the co-expression of $D a v A B$ and GabDT in one cell would have a negative interaction. Considering these results, we established a microbial consortium based whole-cell system composed of E. coli BL21-22AB and E. coli BL21-YDT (Figure 3A) to eliminate the activity imbalance of $\operatorname{DavAB}$ and $G a b D T$, as well as the interaction of gene expression in a single cell.

\section{Engineering a Microbial Consortium for Glutarate Production via the Whole-Cell Process}

The performance of the microbial consortium based wholecell system was first evaluated by the determination of 5-AMV accumulation and glutarate production, while the whole-cell BL21-22AB-YDT was performed as the control (Figures 3B,C). For the microbial consortium based whole-cell system, the E. coli BL21-22AB and E. coli BL21-YDT were added into the bioconversion mixture with an $\mathrm{OD}_{600}$ of 10 , respectively. As the results shown in Figure 3B, $16.3 \mathrm{~g} / \mathrm{L}$ glutarate was obtained from $20 \mathrm{~g} / \mathrm{L}$ L-lysine with a molar yield of $90.2 \%$ after bioconversion of $70 \mathrm{~h}$. For the 5-AMV variance in the microbial consortium based whole-cell system, it accumulated to $2.3 \mathrm{~g} / \mathrm{L}$ at the beginning of $30 \mathrm{~h}$. After that, the 5-AMV concentration gradually reduced to $1.01 \mathrm{~g} / \mathrm{L}$ at $74 \mathrm{~h}$ (Figure 3C). For the control group, $8.9 \mathrm{~g} / \mathrm{L}$ of glutarate was produced after bioconversion of $74 \mathrm{~h}$ with a yield of $49.2 \%$, and $5.4 \mathrm{~g} / \mathrm{L} 5-\mathrm{AMV}$ was accumulated when $E$. coli BL21-22AB-YDT was used as the whole-cell biocatalysts with an 


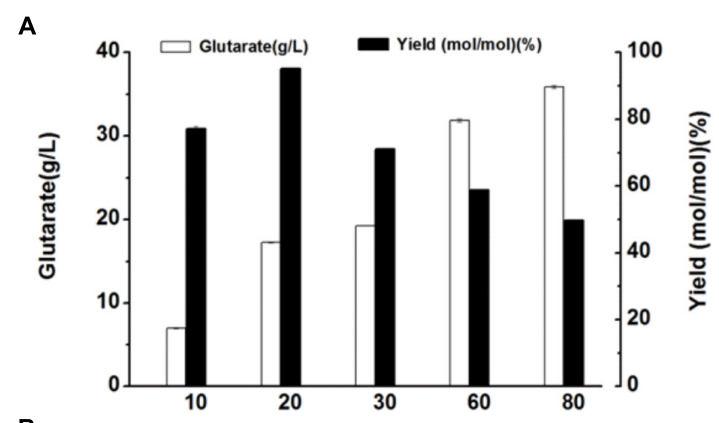

B

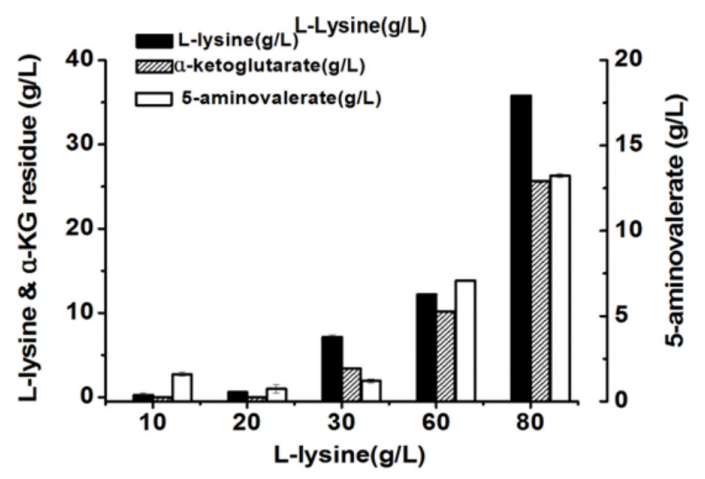

C

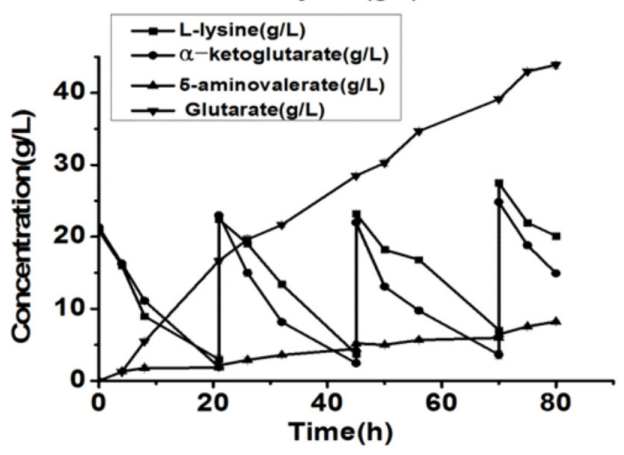

FIGURE 6 | The production of glutarate from L-lysine via the microbial consortium based whole-cell system. (A) The glutarate production from the different concentrations of L-lysine with the microbial consortium based whole-cell system after bioconversion of $70 \mathrm{~h}$; (B) The L-lysine and $\alpha-K G$ residue, and 5-AMV accumulation with the microbial consortium based whole-cell system after bioconversion of $70 \mathrm{~h}$; (C) A fed-batch strategy for glutarate production of from L-lysine with the microbial consortium based whole-cell system. The L-lysine consumption, $\alpha-K G$ consumption, 5-AMV accumulation, and glutarate production during the fed-batch bioconversion were detected.

$\mathrm{OD}_{600}$ of 10 (Figures 3B,C). With an $\mathrm{OD}_{600}$ of 20 , the glutarate titer was $10.9 \mathrm{~g} / \mathrm{L}$, and $3.6 \mathrm{~g} / \mathrm{L}$ 5-AMV was accumulated finally (Figures 3B,C). Obviously, the microbial consortium based whole-cell system could reduce the intermediate accumulation and enhance glutarate yield efficiently.

\section{Optimizing Conditions of the Microbial Consortium Based Whole-Cell System}

The optimal cultivation conditions of E. coli BL21-22AB have been identified in the previous study (Wang et al., 2016). To make the whole-cell system more efficient, the cultivation conditions of E. coli BL21-YDT including induction time, temperature, and IPTG concentration were optimized. As shown in Figures 4A,B, the optimal induction time and temperature of BL21-YDT were observed during the stationary phase $\left(\mathrm{OD}_{600}=2.0\right)$ at $20^{\circ} \mathrm{C}$. Additionally, titration of various IPTG concentrations ranging from 0.1 to $1 \mathrm{mM}$ allowed assessment of glutarate production, which peaked at the IPTG concentration of $0.5 \mathrm{mM}$ (Figure 4C).

To further improve biocatalytic efficiency, the bioconversion conditions, including reaction temperature, reaction $\mathrm{pH}$, metal ion additive, and cell ratio were also optimized. The effect of reaction temperature on glutarate production was shown in Figure 5A. Following bioconversion at 20, 30, 37, 45, or $55^{\circ} \mathrm{C}$ for $30 \mathrm{~h}$, we observed optimal glutarate production at $37^{\circ} \mathrm{C}$. The effect of reaction $\mathrm{pH}$ on glutarate production was shown in Figure 5B. The results indicated that glutarate production achieved the highest level when reaction $\mathrm{pH}$ was at 7.4. The effects of metal ions on glutarate production in the microbial consortium based whole-cell system were shown in Figure 5C. The results indicated that the addition of $\mathrm{Cu}^{2+}$ exhibited positive effects with a 1.2-fold higher glutarate production. The addition of $\mathrm{Ca}^{2+}$ did not affect whole-cell catalytic activity, whereas the addition of $\mathrm{Zn}^{2+}, \mathrm{Fe}^{3+}, \mathrm{Fe}^{2+}, \mathrm{K}^{+}, \mathrm{Mg}^{2+}, \mathrm{Co}^{2+}, \mathrm{Mn}^{2+}$, or $\mathrm{Sr}^{2+}$ exhibited negative effects. The presence of $\mathrm{Co}^{2+}$ and $\mathrm{Fe}^{2+}$ drastically decreased the whole-cell catalytic activity (Figure 5C).

As the accumulation of 5-AMV, we inferred that the activity of GabDT might be critical for glutarate productivity. One of the advantages for the microbial consortium is that the cell ratio could be easily adjusted. Thus, we attempted to increase the ratio of BL21-YDT in the whole-cell system to evaluate its effect on glutarate production (Figure 5D). Increasing the ratio of BL21YDT in the whole cell system improved glutarate production to some extent. When the ratio of BL21-22AB and BL21-YDT was below 1:3, glutarate production was poor with a molar yield lower than $50 \%$. Obviously, when the ratio of BL21-22AB and BL21-YDT was set as 1:3, glutarate production achieved the highest level (Figure 5D). However, the production presented slowly descend tendency with the increasing ratio of BL21YDT continuously. Thus the appropriate ratio of two strains was important for the glutarate productivity in our microbial consortium based whole-cell system.

\section{The Production of Glutarate From L-Lysine via the Microbial Consortium Based Whole-Cell System}

Under the optimal conditions, glutarate production from L-lysine using the E. coli BL21-22AB and E. coli BL21-YDT coupling whole-cell system was performed with the different concentrations of L-lysine ranking from 10 to $80 \mathrm{~g} / \mathrm{L}$. As shown in Figure 6A, the glutarate titer was increased with the increasing L-lysine concentration. However, we found the glutarate yield achieved the highest level of $95.1 \%$ under the condition of $20 \mathrm{~g} / \mathrm{L} \mathrm{L}$-lysine, and then gradually reduced when the L-lysine concentration increased from 30 to $80 \mathrm{~g} / \mathrm{L}$ (Figure 6A). Compared to the single strain based whole-cell system, the glutarate production and yield were all significantly improved (Table 2). For example, the highest glutarate yield in the 
TABLE 2 | The performance comparison of the microbial consortium based whole-cell system with that of single strain based whole-cell system.

\begin{tabular}{|c|c|c|c|c|c|c|}
\hline \multirow{2}{*}{$\begin{array}{c}\text { Initial L-lysine } \\
\text { concentration } \\
\text { (g/L) }\end{array}$} & \multicolumn{2}{|c|}{ 5- aminovalerate accumulation ( $g / L)$} & \multicolumn{2}{|c|}{ Glutarate production (g/L) } & \multicolumn{2}{|c|}{ Glutarate molar yied (\%) } \\
\hline & $\begin{array}{c}\text { E. coli } \\
\text { BL21-22AB-YDT }\end{array}$ & $\begin{array}{c}\text { E. coli BL21-22AB } \\
\text { and } E \text {. coli BL21-YDT }\end{array}$ & $\begin{array}{c}\text { E. coli } \\
\text { BL21-22AB-YDT }\end{array}$ & $\begin{array}{c}\text { E. coli BL21-22AB } \\
\text { and } E \text {. coli BL21-YDT }\end{array}$ & $\begin{array}{c}\text { E. coli } \\
\text { BL21-22AB-YDT }\end{array}$ & $\begin{array}{c}\text { E. coli BL21-22AB } \\
\text { and } E \text {. coli BL21-YDT }\end{array}$ \\
\hline 10 & 1.98 & 1.59 & 5.79 & $6.97^{* *}$ & 64.02 & $77.10^{* *}$ \\
\hline 20 & 4.55 & $0.74^{* *}$ & 13.73 & $17.24^{* *}$ & 75.90 & $95.15^{* * *}$ \\
\hline 30 & 8.18 & $1.21^{* * *}$ & 18.23 & $19.23^{* *}$ & 67.21 & $70.95^{* *}$ \\
\hline 60 & 12.71 & $7.09^{* * *}$ & 22.22 & $31.86^{* * *}$ & 40.97 & $58.76^{* * *}$ \\
\hline 80 & 17.23 & $13.23^{* *}$ & 18.87 & $35.88^{* * *}$ & 26.10 & $49.63^{* * *}$ \\
\hline
\end{tabular}

Significance levels of students t-test, ${ }^{*} P<0.05,{ }^{*} P<0.01,{ }^{* * *} P<0.001$ for the performance of microbial consortium compared to the single strain.

single strain based whole-cell system was $75.9 \%$ at a lysine concentration of $20 \mathrm{~g} / \mathrm{L}$.

The accumulation of 5-AMV was also monitored. As the results in Figure 6B, little 5-AMV could be detected when the lysine concentration was lower than $30 \mathrm{~g} / \mathrm{L}$ in our microbial consortium based whole-cell system. Even under a higher lysine concentration of $80 \mathrm{~g} / \mathrm{L}$, the accumulation of 5-AMV was reduced to 13.23 , which is $17.23 \mathrm{~g} / \mathrm{L}$ in the single strain based wholecell system (Table 2 ). The largely reduced 5-AMV accumulation and increased glutarate production indicated that engineering microbial consortium, each of which contains the part of the pathway, was an efficient strategy to reduce the pathway imbalance for the improvement of glutarate productivity.

Finally, a fed-batch strategy to maintain L-lysine concentration at $20 \mathrm{~g} / \mathrm{L}$ was performed in a $1 \mathrm{~L}$ fermenter. The result was shown in Figure 6C. $16.7 \mathrm{~g} / \mathrm{L}$ glutarate was produced after bioconversion of $21 \mathrm{~h}$ with an average productivity of $0.79 \mathrm{~g} / \mathrm{L} / \mathrm{h}$. Meanwhile, lysine, and $\alpha-\mathrm{KG}$ were almost exhausted and the substrates were added into the bioconversion mixture. We observed that the glutarate production increased to $28.5 \mathrm{~g} / \mathrm{L}$ from 21 to $45 \mathrm{~h}$ with an average productivity of $0.49 \mathrm{~g} / \mathrm{L} / \mathrm{h}$. In the third batch from 45 to $70 \mathrm{~h}$, glutarate titer was increased to $39.1 \mathrm{~g} / \mathrm{L}$ with an average productivity of $0.42 \mathrm{~g} / \mathrm{L} / \mathrm{h}$. After that, the substrate consumption rate decreased to a relatively low level, and no obvious increase in glutarate synthesis was observed with the addition of L-lysine. Finally $43.8 \mathrm{~g} / \mathrm{L}$ glutarate was obtained after bioconversion of $80 \mathrm{~h}$, which was the highest value reported to date.

\section{DISCUSSION}

In recent years, several $\mathrm{C} 3$ and $\mathrm{C} 4$ chemicals have been successfully produced in recombinant microorganisms as the potential platform chemicals for synthesis of other value-added chemicals (Zhang et al., 2017). Glutarate is an attractive C5 building block for the production nylon-5,5 and other C5-derived polyesters from renewable feedstocks (Adkins et al., 2013; Park et al., 2014). Here, we developed a whole-cell bioconversion system with recombinant $E$. coli strains for the production of glutarate from L-lysine.

With the recombinant $E$. coli that co-expressed four genes (DavB, DavA, GabD, and GabT) involved in 5-AMV pathway as the whole-cell catalysts, the highest titer of $22.2 \mathrm{~g} / \mathrm{L}$ glutarate was obtained from $60 \mathrm{~g} / \mathrm{L}$ L-lysine with a yield of $41 \%$. We further identified that the intermediate 5-AMV was largely accumulated, which might be one of important factors limiting glutarate production. Previous studies have indicated that imbalances within metabolic pathways could lead to the accumulation of intermediate metabolites in multiple gene pathways (Xu et al., 2013). The imbalance of DavAB and GabDT activities in E. coli BL21-22BA-YDT was also confirmed here. In addition, when the four genes were co-expressed in one strain, the decreased $D a v A B$ and GabDT activities are both observed. Moreover, the GabDT activity was more negatively affected by the expression of $\operatorname{Dav} A B$ compared to the effect of GabDT expression on $D a v A B$ activity. Overexpression of multiple genes in one recombinant host cell often utilizes a significant amount of the host cell's resources, removing those resources away from host cell metabolism and placing a metabolic load (metabolic drain, metabolic burden) on the cell to support a highly expressed foreign pathway (Glick, 1995). The biochemistry and physiology of the host may change significantly due to the imposed metabolic load, resulting in deleterious outcomes for the recombinant protein (Cao et al., 2016; Horga et al., 2018). The co-expression of DavAB and GabDT in one strain might overload the host's capacity and further affected their expression resulting in decreased activity. As DavAB was expressed on a high copy number plasmid (pET22b) and GabDT on a low copy number plasmid (pACYCDuet-1), the GabDT, which was disadvantage in quantity, might be affected more significantly.

In recent years, the synthetic microbial consortium has attracted researchers' attention as an alternative strategy to reduce the metabolic imbalance for the synthesis valueadded chemicals (Brenner et al., 2008). In addition, this design will simplify the optimization of each reaction in the pathway, so that the time required for making the product would be substantially reduced (Brenner et al., 2008). Several reports have successfully achieved the production of biofuels and chemicals by the synthetic consortia comprising genetically engineered microbes (Bayer et al., 2009; Xia et al., 2012; Minty et al., 2013). Therefore, we attempted to develop a synthetic microbial consortia system through expression of $D a v A B$ and GabDT in two divided E. coli strains for glutarate production. Exactingly, this synthetic microbial consortia based whole-cell system effectively reduced the accumulation of intermediate 5-AMV, and 
the glutarate yield could reach $95.1 \%$ under the optimal L-lysine concentration. With a fed-batch strategy, a final glutarate titer of $43.8 \mathrm{~g} / \mathrm{L}$ was achieved.

However, there are still some limitations in our bioconversion system. For example, during the production of 5-AMV, $120 \mathrm{~g} / \mathrm{L}$ L-lysine could be consumed within $5 \mathrm{~h}$ (Wang et al., 2016). However, L-lysine could not be totally exhausted after bioconversion of $70 \mathrm{~h}$ even under the condition of $30 \mathrm{~g} / \mathrm{L}$ L-lysine as shown in our results. We inferred that the production of glutarate might have an inhibition on the substrate conversion, which will be focused on in our following study for the further improvement of glutarate production.

\section{AUTHOR CONTRIBUTIONS}

XW and RS designed the experiments, generated all strains for this work, performed the bioconversion experiments, prepared the figures, and contributed to the writing of the manuscript. SX and JF helped draft the manuscript. KC conceived the study, directed the experiments, and helped draft the manuscript. PO contributed ideas to the project. All authors contributed to the analysis and interpretation of data. All authors approved the manuscript submitted.

\section{REFERENCES}

Adkins, J., Jordan, J., and Nielsen, D. R. (2013). Engineering Escherichia coli for renewable production of the 5-carbon polyamide building-blocks 5aminovalerate and glutarate. Biotechnol. Bioeng. 110, 1726-1734. doi: 10.1002/ bit. 24828

Baldwin, A. F., Ma, R., Mannodi-Kanakkithodi, A., Huan, T. D., Wang, C., Tefferi, M., et al. (2015). Poly(dimethyltin glutarate) as a prospective material for high dielectric applications. Adv. Mater. 27, 346-351. doi: 10.1002/adma. 201404162

Bayer, T. S., Widmaier, D. M., Temme, K., Mirsky, E. A., Santi, D. V., and Voigt, C. A. (2009). Synthesis of methyl halides from biomass using engineered microbes. J. Am. Chem. Soc. 131, 6508-6515. doi: 10.1021/ja809 $461 \mathrm{u}$

Brenner, K., You, L., and Arnold, F. H. (2008). Engineering microbial consortia: a new frontier in synthetic biology. Trends Biotechnol. 26, 483-489. doi: 10.1016/ j.tibtech.2008.05.004

Cao, W., Ma, W., Wang, X., Zhang, B., Cao, X., Chen, K., et al. (2016). Enhanced pinocembrin production in Escherichia coli by regulating cinnamic acid metabolism. Sci. Rep. 6:32640. doi: 10.1038/srep32640

Chen, Y., and Nielsen, J. (2016). Biobased organic acids production by metabolically engineered microorganisms. Curr. Opin. Biotechnol. 37, 165-172. doi: 10.1016/j.copbio.2015.11.004

Dahl, R. H., Zhang, F., Alonso-Gutierrez, J., Baidoo, E., Batth, T. S., ReddingJohanson, A. M., et al. (2013). Engineering dynamic pathway regulation using stress-response promoters. Nat. Biotechnol. 31, 1039-1046. doi: 10.1038/nbt. 2689

Eggeling, L., and Bott, M. (2015). A giant market and a powerful metabolism: 1-lysine provided by Corynebacterium glutamicum. Appl. Microbiol. Biotechnol. 99, 3387-3394. doi: 10.1007/s00253-015-6508-2

Glick, B. R. (1995). Metabolic load and heterologous gene expression. Biotechnol. Adv. 13, 247-261. doi: 10.1016/0734-9750(95) 00004-A

Gobin, M., Loulergue, P., Audic, J.-L., and Lemiègre, L. (2015). Synthesis and characterisation of bio-based polyester materials from vegetable oil and short

\section{FUNDING}

This study was supported by the National Nature Science Foundation of China (Grant Nos. 21576134, 21606127, 21390200, and 21706126) and the National Key Research and Development Program of China (Grant No. 2016YFA0204300).

\section{ACKNOWLEDGMENTS}

The authors thank the financial support by the Open Funding Project of the State Key Laboratory of Bioreactor Engineering.

\section{SUPPLEMENTARY MATERIAL}

The Supplementary Material for this article can be found online at: https://www.frontiersin.org/articles/10.3389/fmicb. 2019.00341/full\#supplementary-material

FIGURE S1 | SDS-PAGE analysis of the cell-free extract of the recombinant strain BL-22AB, and BL-YDT and BL-22AB-YDT. All the lanes were loaded with an equal amount of protein.

TABLE S1 | Evaluating the performance of the microbial consortium based whole-cell system.

to long chain dicarboxylic acids. Ind. Crops Prod. 70, 213-220. doi: 10.1016/j. indcrop.2015.03.041

Horga, L. G., Halliwell, S., Castiñeiras, T. S., Wyre, C., Matos, C. F. R. O., Yovcheva, D. S., et al. (2018). Tuning recombinant protein expression to match secretion capacity. Microb. Cell Fact. 17:199. doi: 10.1186/s12934-018-1047-z

Liu, P., Zhang, H., Lv, M., Hu, M., Li, Z., Gao, C., et al. (2014). Enzymatic production of 5-aminovalerate from 1-lysine using 1-lysine monooxygenase and 5-aminovaleramide amidohydrolase. Sci. Rep. 4:5657. doi: 10.1038/srep 05657

Lu, L., Huggins, T., Jin, S., Zuo, Y., and Ren, Z. J. (2014). Microbial metabolism and community structure in response to bioelectrochemically enhanced remediation of petroleum hydrocarbon-contaminated soil. Environ. Sci. Technol. 48, 4021-4029. doi: 10.1021/es4057906

Ma, W., Cao, W., Zhang, H., Chen, K., Li, Y., and Ouyang, P. (2015). Enhanced cadaverine production from l-lysine using recombinant Escherichia coli cooverexpressing CadA and CadB. Biotechnol. Lett. 37, 799-806. doi: 10.1007/ s10529-014-1753-5

Miksch, G., Bettenworth, F., Friehs, K., Flaschel, E., Saalbach, A., Twellmann, T., et al. (2005). Libraries of synthetic stationary-phase and stress promoters as a tool for fine-tuning of expression of recombinant proteins in Escherichia coli. J. Biotechnol. 120, 25-37. doi: 10.1016/j.jbiotec.2005.04.027

Minty, J. J., Singer, M. E., Scholz, S. A., Bae, C.-H., Ahn, J.-H., Foster, C. E., et al. (2013). Design and characterization of synthetic fungal-bacterial consortia for direct production of isobutanol from cellulosic biomass. Proc. Natl. Acad. Sci. U.S.A. 110, 14592-14597. doi: 10.1073/pnas.1218447110

Oh, Y. H., Kang, K.-H., Kwon, M. J., Choi, J. W., Joo, J. C., Lee, S. H., et al. (2015). Development of engineered Escherichia coli whole-cell biocatalysts for highlevel conversion of 1-lysine into cadaverine. J. Ind. Microbiol. Biotechnol. 42, 1481-1491. doi: 10.1007/s10295-015-1678-6

Okino, S., Noburyu, R., Suda, M., Jojima, T., Inui, M., and Yukawa, H. (2008). An efficient succinic acid production process in a metabolically engineered Corynebacterium glutamicum strain. Appl. Microbiol. Biotechnol. 81, 459-464. doi: 10.1007/s00253-008-1668-y

Paris, G., Berlinguet, L., Gaudry, R., English, J., and Dayan, J. E. (2003). Glutaric Acid and Glutarimide. Organic Synth. 4:496. 
Park, S. J., Kim, E. Y., Noh, W., Park, H. M., Oh, Y. H., Lee, S. H., et al. (2013). Metabolic engineering of Escherichia coli for the production of 5-aminovalerate and glutarate as C5 platform chemicals. Metab. Eng. 16, 42-47. doi: 10.1016/j. ymben.2012.11.011

Park, S. J., Oh, Y. H., Noh, W., Kim, H. Y., Shin, J. H., Lee, E. G., et al. (2014). High-level conversion of L-lysine into 5-aminovalerate that can be used for nylon 6, 5 synthesis. Biotechnol. J. 9, 1322-1328. doi: 10.1002/biot.2014 00156

Rohles, C. M., Gießelmann, G., Kohlstedt, M., Wittmann, C., and Becker, J. (2016). Systems metabolic engineering of Corynebacterium glutamicum for the production of the carbon-5 platform chemicals 5-aminovalerate and glutarate. Microb. Cell Fact. 15:154. doi: 10.1186/s12934-016-0553-0

Salis, H. M., Mirsky, E. A., and Voigt, C. A. (2009). Automated design of synthetic ribosome binding sites to control protein expression. Nat. Biotechnol. 27, 946-950. doi: 10.1038/nbt.1568

Smolke, C. D., Martin, V. J. J., and Keasling, J. D. (2001). Controlling the metabolic flux through the carotenoid pathway using directed mRNA processing and stabilization. Metab. Eng. 3, 313-321. doi: 10.1006/mben. 2001.0194

Tsuge, Y., Kawaguchi, H., Sasaki, K., and Kondo, A. (2016). Engineering cell factories for producing building block chemicals for bio-polymer synthesis. Microb. Cell Fact. 15:19. doi: 10.1186/s12934-016-0411-0

Vafaeezadeh, M., and Hashemi, M. M. (2016). A non-cyanide route for glutaric acid synthesis from oxidation of cyclopentene in the ionic liquid media. Process Saf. Environ. Prot. 100, 203-207. doi: 10.1016/j.psep.2016.01.011

Wang, J., Wu, Y., Sun, X., Yuan, Q., and Yan, Y. (2017). De novo biosynthesis of glutarate via $\alpha$-Keto acid carbon chain extension and decarboxylation pathway in Escherichia coli. ACS Synth. Biol. 6, 1922-1930. doi: 10.1021/acssynbio. $7 \mathrm{~b} 00136$

Wang, X., Cai, P., Chen, K., and Ouyang, P. (2016). Efficient production of 5-aminovalerate from l-lysine by engineered Escherichia coli whole-cell biocatalysts. J. Mol. Catal. B Enzym. 134, 115-121. doi: 10.1016/j.molcatb.2016. 10.008

Williams, J. B., Chapman, T. M., and Hercules, D. M. (2003). Synthesis of Discrete Mass Poly(butylene glutarate) Oligomers. Macromolecules 36, 3898-3908. doi: $10.1021 / \mathrm{ma} 021056 \mathrm{~b}$
Xia, T., Eiteman, M. A., and Altman, E. (2012). Simultaneous utilization of glucose, xylose and arabinose in the presence of acetate by a consortium of Escherichia coli strains. Microb. Cell Fact. 11:77. doi: 10.1186/1475-2859-11-77

Xu, P., Gu, Q., Wang, W., Wong, L., Bower, A. G. W., Collins, C. H., et al. (2013). Modular optimization of multi-gene pathways for fatty acids production in E. coli. Nat. Commun. 4:1409. doi: 10.1038/ncomms 2425

Yang, J. E., Park, S. J., Kim, W. J., Kim, H. J., Kim, B. J., Lee, H., et al. (2018). One-step fermentative production of aromatic polyesters from glucose by metabolically engineered Escherichia coli strains. Nat. Commun. 9:79. doi: 10. 1038/s41467-017-02498-w

Ying, H. X., Wang, J., and Chen, K. Q. (2015). Enhanced conversion of 1-lysine to 1-pipecolic acid using a recombinant Escherichia coli containing lysine cyclodeaminase as whole-cell biocatalyst. J Mol Catal B Enzym. 117, 75-80. doi: 10.1016/j.molcatb.2015.05.001

Yu, J.-L., Xia, X.-X., Zhong, J.-J., and Qian, Z.-G. (2017). A novel synthetic pathway for glutarate production in recombinant Escherichia coli. Process Biochem. 59, 167-171. doi: 10.1016/j.procbio.2017.06.026

Zhang, Y., Liu, D., and Chen, Z. (2017). Production of C2-C4 diols from renewable bioresources: new metabolic pathways and metabolic engineering strategies. Biotechnol. Biofuels 10:299. doi: 10.1186/s13068-0170992-9

Zhao, X., Bansode, S. R., Ribeiro, A., Abreu, A. S., Oliveira, C., Parpot, P., et al. (2016). Ultrasound enhances lipase-catalyzed synthesis of poly (ethylene glutarate). Ultrason. Sonochem. 31, 506-511. doi: 10.1016/j.ultsonch.2016. 02.005

Conflict of Interest Statement: The authors declare that the research was conducted in the absence of any commercial or financial relationships that could be construed as a potential conflict of interest.

Copyright (c) 2019 Wang, Su, Chen, Xu, Feng and Ouyang. This is an open-access article distributed under the terms of the Creative Commons Attribution License (CC BY). The use, distribution or reproduction in other forums is permitted, provided the original author(s) and the copyright owner(s) are credited and that the original publication in this journal is cited, in accordance with accepted academic practice. No use, distribution or reproduction is permitted which does not comply with these terms. 